\title{
FEMALE FIGURES OF THE JAZZ AGE IN DOROTHY PARKER'S SHORT STORIES
}

\author{
Isabel López Cirugeda \\ University of Castilla-La Mancha (Spain)
}

\begin{abstract}
Most criticism on Dorothy Parker (1893-1967) highlights her literary persona only to the detriment of the study of a profuse work comprising six decades of narrative, poetry and drama. Probably her best-known contribution to literature was her condition of the voice of the Jazz Age generation, shifting from acquiescence to irony. A corpus of Parker's short stories written in the 1920s and early 1930s will be analyzed from feminist perspectives, such as those by Pettit, Melzer or Showalter, in terms of 'appearance', 'social life' and 'bonds with men' to determine whether her heroines respond to the stereotype of the flapper in the Roaring Twenties. Results show a satirized viewpoint conveying dissatisfaction regarding body, idleness and romance predicting many of the conflicts of women in the second half of the XXth century.
\end{abstract}

Keywords: Dorothy Parker, short stories, flappers, Jazz Age, feminist criticism, body, satire.

\section{Resumen}

La mayor parte de los estudios sobre Dorothy Parker (1893-1967) se centran en su condición de personalidad del panorama escénico en detrimento de su profusa obra, con más de seis decenios de narrativa, poesía y teatro. Probablemente su contribución más reconocida sea haber dado voz a la generación de la Era del Jazz, con una visión que oscila entre la complicidad y la ironía. Las heroínas del corpus de relatos escritos por Parker en los años veinte y treinta serán analizadas bajo perspectivas feministas (Pettit, Melzer, Showalter) en términos de 'apariencia', 'vida social' y 'relación con los hombres' para determinar si se acomodan al estereotipo de la flapper. Los resultados muestran una sátira del modelo insatisfecho con su cuerpo y la vacuidad de su vida y amoríos que anuncia conflictos femeninos de la segunda mitad del siglo XX.

Palabras clave: Dorothy Parker, relatos, flappers, Era del Jazz, crítica feminista, cuerpo, sátira. 


\section{Dorothy Parker, the 'smartest girl in New York'}

Most criticism on Dorothy Parker (1893-1967) has traditionally focused on her role as the main attraction of the Vicious Circle of the Algonquin Round Table, a dynamic group including some of the major personalities of the Broadway scene in the late 1920s, most of them humorists, such as Alexander Woollcott, George Kaufman or Harpo Marx. The group attained almost instant notoriety as their daily gatherings in the Midtown Manhattan Algonquin hotel were weekly reported by one of their founding members, Franklin Pierce Adams, in his popular column The Conning Tower for The New York Tribune. This selfpromotion, which made them earn the nickname of 'log rollers', was the identity sign of the Algonquinites together with their particular kind of humor, regarded as too cultivated to be considered popular culture, and too light-hearted to enter the classical canon, and which would be later labeled as quintessentially 'middlebrow'. Their production, for which they were called "the first literary generation of America" (Gaines 24), seemingly fits this category of 'smart' entertainment, and insistently deals with the war of sexes and their ludicrous self-consideration as elite, based on the uniqueness of their own place and times, that is, to a playful lifestyle, including endless parties and trips, provided by New York in the Roaring Twenties, especially from their privileged jobs in the media and the show business.

This publicity is considered a key factor of the rising of Dorothy Parker (Miller 120), since her anecdotes and epigrams were often quoted among the funniest out of a posse specifically characterized by loudness and wit, and the awareness of having an audience made her embark on a literary career out from her position as a theatre critic -the same Willa Cather had twenty years beforeHowever, her fame also worked as a drawback in the long run, as compilations of her witticism have mostly replaced an in-depth study of a profuse, varied work comprising six decades of narrative, poetry and drama. ${ }^{1}$ Her reputation as a wit has also misled the consideration of her production as humorous, which could be regarded only as partially true, since both loneliness and miscommunication are her main topics and the presence of a nineteenth-century sentimental tone becomes a hallmark of her writings together with her satiric register (Pettit, The critical 18). Criticism on her work is also expanding its area of study since it

\footnotetext{
${ }^{1}$ Nowadays, a growing interest in her literary persona seems to be proved by recent reeditions as The Portable Dorothy Parker or The ladies of the corridor, both edited by Meade, her main biographer; reeditions in different languages together with new compilations of her poems like the compilation Not much fun. See, for instance, the musical Not much fun (Goulet), the songs by Prince, Niki Lee or Carla Bruni or the plays You might as well live (adapted by Frederickson) or No sense saying goodnight (adapted by Thusing). There has also been extensive vindication of her work by Rubinstein or Villena among others and, especially, by the launching of the Dorothy Parker Society in 1998 (http://www.dorothyparker.com/).
} 
comprehends a variety of aspects from the overview on her main accomplishments made on her own times or soon after (Kinney) to the more modern research, often concerning her controversial position towards Modernism (Pettit, A gendered) or feminism (Melzer).

Probably Parker's best-known contribution to literature was her condition of the voice of a generation, the Jazz Age, as, according to critic and editor Edmund Wilson, she "put into what she [wrote] a voice, a state of mind, an era, a few moments of human experience no one else has conveyed" (68). Consequently, the aim of this paper is to explore the thirty-five short stories written by Dorothy Parker between 1922 and 1933 out from her total production of forty-eight stories. As there is no unanimity regarding the collection of Dorothy Parker's stories, the corpus used will be the selection proposed by Breese in 1995 even if it slightly differs with the one by Calhoun (51-53) as every short story can be easily found in just one volume, Complete Stories (Parker). Most of them belong to the category of the so-called 'sketches', a kind of dramatized situations normally played by a man and a woman in a festive atmosphere which were published in The New Yorker. Here is the complete list (dates have been added to follow chronology):

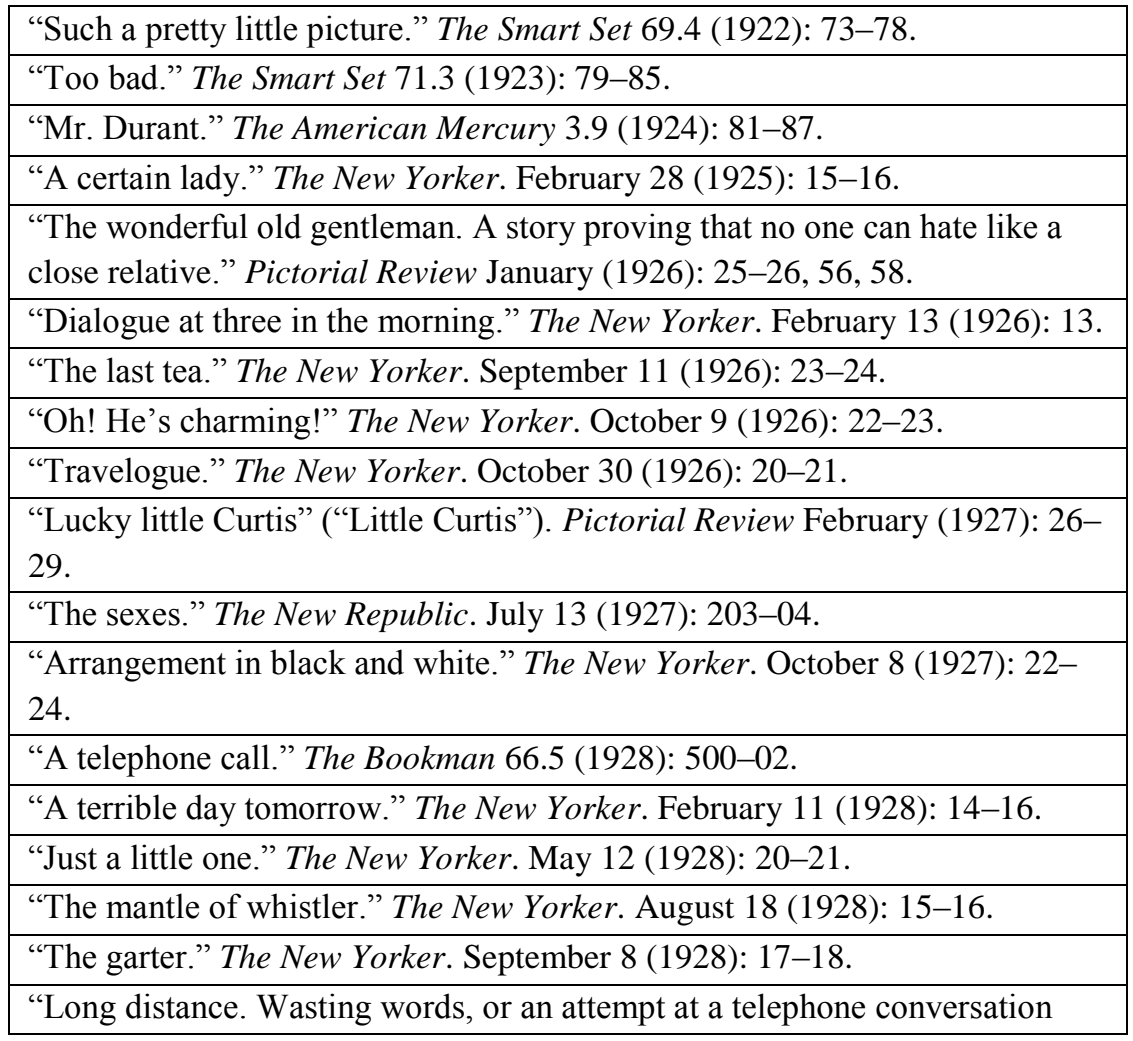




\begin{tabular}{|c|}
\hline $\begin{array}{l}\text { between New York and Detroit" (“New York to Detroit"). Vanity Fair. } \\
\text { October (1928): } 61 .\end{array}$ \\
\hline "Big blonde." The Bookman 68.6 (1929): 639-50. \\
\hline "You were perfectly fine." The New Yorker. February 23 (1929): 17. \\
\hline "The cradle of civilization." The New Yorker. September 21 (1929): 23-24. \\
\hline "But the one on the right." The New Yorker. October 19 (1929): 25-27. \\
\hline "Here we are." Cosmopolitan. March (1931): 32-35, 98. \\
\hline "Lady with a lamp." Harper's Bazaar. April (1932): 56-57, 102, 104. \\
\hline $\begin{array}{l}\text { "Dusk before fireworks.” Harper's Bazaar. September (1932): 36-37, 90, } \\
\text { 92, 94, } 96 .\end{array}$ \\
\hline $\begin{array}{l}\text { "A young woman in green lace." The New Yorker. September } 24 \text { (1932): 15- } \\
17 .\end{array}$ \\
\hline "Horsie." Harper's Bazaar. December (1932): 66-67, 118, 120-21,124. \\
\hline $\begin{array}{l}\text { "Advice to the little Peyton girl." Harper's Bazaar. February (1933): 46-47, } \\
84,86 .\end{array}$ \\
\hline $\begin{array}{l}\text { "From the diary of a New York lady during days of panic, frenzy, and world } \\
\text { change." The New Yorker. March } 25 \text { (1933): 13-14. }\end{array}$ \\
\hline "Sentiment..." Harper's Bazaar. May (1933): 64-65, 113. \\
\hline "Mrs. Carrington and Mrs. Crane." The New Yorker. July 13 (1933): 11-12. \\
\hline "The little hours." The New Yorker. August 19 (1933): 13-14. \\
\hline "The Waltz." The New Yorker. September 2 (1933): 11-12. \\
\hline "The road home." The New Yorker. September 16 (1933): 17-18. \\
\hline $\begin{array}{l}\text { "Glory in the daytime." Harper's Bazaar. September (1933): 50-51, 122, } \\
124,126-127 .\end{array}$ \\
\hline
\end{tabular}

Table 1. Corpus of Dorothy Parker's stories (1922-33).

This paper aims to determine the main ways in which this period is depicted and how the characters respond to the model of the flapper and the more 
traditional Victorian female stereotype as described by feministic criticism (Showalter) in terms of their 'appearance', 'social life' and 'bonds to men'. The choice for this specific period is not random, as in these years she covered the above-mentioned main achievement of portraying the middle and upper-class New Yorkers in the Roaring Twenties. The short stories written from 1929 to 1933, right after the Wall Street Crash, were also included under the consideration they belong to a first period of Parker's experimentation with narrative, previous to Alan Campbell, her own second husband and main collaborator, and well into the awakening of her political commitment, in her Algonquinite period and in the prime of her fame.

\section{The flapper as the 'New Woman'}

The thirty-five short stories of the selected corpus seem to respond to a deliberate aim to innovate, as the most canonical pieces ("Such a little pretty picture") are mixed with dramatized sketches where the presence of the narrator is reduced to minimum ("Travelogue"), to the combination of both techniques ("Too bad") or even the use of monologues ("The garter"). Therefore, it could be inferred that their connection to Modernism is more evident than in later works, in which the stress is usually made on message over style ("Clothe the naked" 244-51).

Regarding the female main characters of the corpus, and there is an open pre-eminence of them over the male ones, there is at least one main character for each story and sometimes two, usually confronted in terms of rivalry. A remarkable trait is the repeated omission of their names, which often appears as a natural consequence of their dramatized nature -names are not known as no one verbalizes them-. But the fact acquires symbolical strength when the lacked names belong to characters that are or feel deprecated in their own surroundings -like the girl in "The last tea" in contrast with the constantly mentioned Carol McCall, her romantic competitor-. Instead, characters are introduced by insubstantial, yet ill-disposed information -in this case, by the fact that of having waited for forty minutes for their date to come (49)-. It also turns significant when they look alike and exchangeable. In fact, some of the names the reader gets to know is Mrs. Legion, a kind of generation standard for snobbish housewives ("A certain lady") and Miss French ("The mantle of whistler"), when Parker insists on the already mentioned popularity of the French style among young girls.

A significant trait of Parker's writing which could point at autobiographical inspiration is that her main characters tend to be older as the author was aging herself. This first group of heroines, accordingly, is mostly composed of dating girls and newly-weds, and through them is felt a pulse of the modern, unconventional world of the Roaring Twenties with more traditional values. This implies a revision of the classic literary stereotypes of the 'femme fatale' and the 'angel of the house', revitalized after the XIXth century under the influence of decadent poets such as Baudelaire and the philosophical thoughts of Nietzsche 
and Schopenhauer at the social impact of the growing power acquired by certain women, which finally crystallized in the 'New Woman' at the turn of the century.

Therefore, the ulterior model known as 'flapper', a term coined by Henry Mencken (1-2) but popularized thanks to Fitzgerald's This Side of Paradise (Curnutt 18), could be considered as a renewed, softer version of the 'dangerous' prototype of the femme fatale that became broadly spread over the United States of America and other Western territories in the 1920s thanks to the influence of the silver screen through the work of the actresses Clara Bow and Louise Brooks. There is a half-mocking, but sympathetic poem, "The flapper" (22), an early work of Parker's condensing her consideration of the matter: they are childish and snobbish, but certainly not as dangerous or remarkable as they are supposed to be. Their success has only to be thanked "to God and Scott Fitzgerald", that is, to their beauty and the enthronization made by the other 'valedictorian' of her own times. This could lead to the impression she scorned the new girl, especially if compared to Edna St Vincent Millay, Parker's main Modernist reference, in her poem "First Fig", where she speaks as one of them in the first person (9). Even more meaningful is the moral sent in the coda closing Parker's poem: "Her golden rule is plain enough- / Just get them young and treat them / Rough" (22).

Even when many examples of the stereotype are logically shown in Parker's stories of the late twenties through a recurrent profile of lively young women especially in her contributions to The New Yorker- the term never appears explicitly in any of them. In order to see if Parker's flappers meet the standards of the modern, unorthodox female roles, they were confronted to the traits set by Showalter for the 'New Woman': a) rejection of conventional female roles, b) redefinition of female sexuality, c) assertion of their rights to higher education and professions and d) social nonconformity and activism (210-11).

Regarding to the first and most general one, that is, the 'rejection of conventional female roles', characters are immersed into a new culture of constant gatherings characterized by extravagant, expensive clothing -as in "From the diary of a New York lady", or "But the one on the right", where the character called Mrs. Parker affirms to be wearing a gold lamé by Louiseboulanger (134)-, the adoption of a French inspired style ("A young woman in green lace"), a kind of particular slang including baby talk linked to a tendency to mother their boyfriends ("The last tea"), which implies a perpetuation of a feminine language in Parker. ${ }^{2}$ Other recurring characteristics

${ }^{2}$ On the subject of Dorothy Parker's modernisation of language, Silverstein recalls on an interview over twenty everyday use terms which are credited to her as she made their first documented use. The list includes 'boy-meets-girl', 'high society', 'nostalgic' or 'queer' (http://www.dorothyparker.com/interview.htm). On the other hand, many studies have remarked the existence of a typically feminine language in Parker's heroines. See for example Treichler (171). 
include some fondness for music, though not necessarily jazz ("The road home"), smoking ("The sexes") and drinking ("Just a little one"), with all the implications for Parker, an alcoholic herself." The second trait, 'redefinition of female sexuality', sends to the new situation among men and women described by Miller under the tag of 'modern love' (108-18): heterosexual relationships, mostly temporary and not linked to marriage, which become explicit in some stories under some hints of premarital sex and homosexuality in the corpus though the latter is not a major topic of the corpus. Two of the three of references are made to lesbian couples into elite, not-so-young environments ("From the diary of a New York lady" and "Glory in the daytime")-. However, Parker remarked the persistence of Victorian values through a preference to show the agony of 'seduced' characters by picturing them ignored ("A telephone call") or even left alone in taboo abortions ("Mr. Durant", "Lady with a lamp"). While most of the stories show a seemingly old-fashioned tension to attract and retain men which makes characters criticise their romantic rivals in terms of age, appearance, habits or moral conduct so as to reaffirm their own value ("Dusk before fireworks"), the only wedding in this first part of her production is made by a virgin ("Here we are"). This panorama of submission to men quite reverses the so-called rejection of the just-mentioned conventional roles.

In reference to the 'assertion of their rights to higher education and professions', some of the characters seem proud of their knowledge -"The little hours"- Nevertheless, none of the characters appear as concerned about their academic training any further than displaying their thoughts into the kind of witty exhibition Parker mastered, while other times their ignorance is evidenced -"The cradle of civilization." The exception is Miss Wilmarth, an efficient nurse who, ironically, is unanimously rejected because of her physical appearance "Horsie"-. The other character who claims to work for her wages, the tipsy lady responsible for the monologue "Just a little one", is also the only one making a comment regarding Showalter's last parameter, 'social nonconformity and activism', as she blames Prohibition for half the crime in her country (92), together with Mrs. Legion who "of politics... says that Mrs. Coolidge is awfully sweet looking [and] that these beggars you see in the street all have big bank accounts" (35). ${ }^{4}$ Therefore, Parker's incipient social commitment is poignantly showed through a generalized shallowness of bourgeois ladies, especially in terms of racial issues, which arise in at least nine stories and become the main topic of "Arrangement in black and white."

${ }^{3}$ Millier thinks she used alcohol as an antidepressant and it affected the amount of her production and the way to perceive her success as failure (19).

${ }^{4}$ Grace Coolidge was President Calvin Coolidge's wife and therefore the First Lady of the United States from 1923 to 1929. The comment appears as even more superficial since the character is ignoring not only the presidential policy, including civil right reforms, but also Mrs. Coolidge's personal tragedy as she had recently lost her younger son, Calvin Jr. in 1924, a year previous to the publication of "A certain lady." 


\section{The Victorian heritage through the bourgeois married woman stereotype}

Meanwhile, in her contributions for other middlebrow magazines, there are examples of slightly older, married characters supposedly representing the opposite stereotype of the 'natural woman' -the one who, by devoting herself to her husband and children is true to her nature, according to patriarchal assumptions- or the 'angel in the house' -the well-known term coined by Patmore's poem-. Neither of these terms seems to fit her characters, even when they mean to, basically as motherhood is almost systematically absent from the corpus. Thus, the main parental bonds are the sinister ones by Mrs. Wheelock ("Such a pretty little picture") and Mrs. Matson ("Little Curtis") and their children while Camilla Cruger is dissatisfied at her new-born baby girl ("Horsie"). The only motherly attention to another woman appearing in the corpus is that in "Advice to the little Peyton girl", and is provided by an older friend. No signs of marital happiness are displayed, either.

Therefore, it might be more useful to classify this collective by other parameters, such as their own perception of themselves as housewives. While some characters are stated as intrinsically discontent at their own performance, such as Mrs. Weldon in "Too bad", some others consider themselves as perfect while the narrator makes the reader think contrariwise through a detailed list of enervating actions and thoughts. This happens in "Such a pretty little picture", and predisposes the reader to side with Mr. Wheelock, the unhandy husband, even when he considers his wife as a highly efficient housekeeper running his own property:

Adelaide was a sterling woman, an utterly faithful wife, an almost slavish mother. She ran his house economically and efficiently. ... She looked after his clothes, gave him medicine when she thought he needed it, oversaw the preparation of every meal that was set before him ...She never lost her temper, she was never depressed, never ill. (9)

The ridicule of the snobbish woman of the middle-up class becomes one of Parker's most noticeable identity signs. Through the stories, many married women repeatedly follow the same patterns: they are compulsively concerned about their image, both physical and projected, meaning the appearance of their homes, the journeys they make or the parties they organize have to offer a worldly, prestigious image. This is an exhausting job they never manage to accomplish, as they are never safe from their friends' malicious comments and not, for sure, from Parker's satirical scope. Conversations in Parker's short stories picture the new obsession with losing weight diets, and the subsequent anxiety about food, the own perceived physical image and its consequences on an inner level by recurrently stressing the superficiality, irrationality and uselessness of the effort together with the ill-intentioned comments about other women ("Mrs. Carrington and Mrs. Crane"). 
In such an environment where couples start to be formed mostly in terms of attraction, physical appearance acquires a vital relevance and ugliness turns into a sad, cruelly-penalized condition. Inside a corpus in which ruthless physical descriptions are so frequent, this aspect appears in many of the stories and becomes a major topic in "Horsie" where the characters get obsessed with the resemblance of a quite old-fashioned, discreet, efficient worker with a horse. As pointed by Melzer (86), "[s]ince Miss Wilmarth has not met the mandatory female 'obligation' to be beautiful, socially she must accept her handicap and fit in as best as she can." Though this can be considered as a vindication of Parker's against the permanence of chauvinistic values, it is not uncommon her own penalizing of women who do not try to look beautiful: "rouge would have been unseemly on her long mouth and perfume on her flat bosom" (173). Other characters, such as Mrs. Wheelock, assume the same policy of keeping themselves apart from cosmetics, but from a point of view based on selfacceptance and rejection to anyone conducting herself contrariwise: "[s]he was wont to tell people, somewhat redundantly, that she never employed any sort of cosmetics" (4). Overweight, smell of cleaning products and glasses become recurrent symbols of ugliness and, thus, social awkwardness throughout the corpus. Women who are not married are unanimously regarded under the social stigma of spinsterhood.

Hazel Morse, the protagonist of "Big blonde", awarded with the 1929 O. Henry to the best short story of the year, is the most devastating example of how lethal beauty can be to a woman. The plot reflects the progressive selfdestruction of a former model representing the Gibson girl type, an exuberant type previous to the flapper, who cannot find other occupation than dating men. The time lapse covered in the story, much more extended than the other ones in the corpus, displays many signs of her inappropriateness for the different female roles offered by her generation. On the one hand, Hazel Morse seems to be genetically expelled from the role of a wife as understood from patriarchal parameters because of the explicit nature of her physical attractive, and yet she invariably attempts to avoid singleness. Furthermore, new social habits, leading to alcoholism, invariably prevents her from finding stability in a partner. On the other hand, she proves to be equally unable to imagine a new path as an independent, single woman. Her lack of initiative is much worsened by the persistent absence of a caring, supporting presence to balance her life. Increasingly concerned about aging, Morse learns her only chance in society is to cling to the role of the careless blond girl.

There is one exception for these tedious, harsh or competitive lifestyles is Camilla Cruger, the beloved wife in "Horsie", who is intensively admired by men, including her own husband, and approved by everyone in her circle. Parker's usually poignant irony turns more subtle so as to make a distinction between pretended and real wealth, which could be the key to that respect. She is said to have used real models as an inspiration: Eleanor Lewis for Mrs. Matson ("Little Curtis"), Gertrude Benchley for Mrs. Wheelock and Adele Lovett for Mrs. Legion and Mrs. Cruger (Meade 12-13, 99, 222), who were, respectively, 
her own stepmother and the wife and lover of Robert Benchley, her best friend in the period covered by this corpus. "Big blonde" is based on her own experiences of divorce, alcohol and suicide attempt.

The examination of the corpus leads to results which can be summarized as follows:

\begin{tabular}{|c|c|c|c|c|c|c|}
\hline TITLE & \multirow{2}{*}{\multicolumn{2}{|c|}{$\begin{array}{c}\text { FEMALE } \\
\text { CHARACTER } \\
\text { Adelaide Wheelock }\end{array}$}} & \multicolumn{2}{|c|}{ LIFESTYLE } & \multicolumn{2}{|c|}{$\begin{array}{l}\text { BONDS WITH } \\
\text { MEN }\end{array}$} \\
\hline $\begin{array}{ll}\text { Such } & \text { a } \\
\text { pretty... }\end{array}$ & & & $\begin{array}{l}\text { Perfect hol } \\
\text { NB-NF }\end{array}$ & ewife & Obliged to & and by her \\
\hline Too bad & \multicolumn{2}{|c|}{ Grace Weldon } & \multicolumn{2}{|c|}{$\begin{array}{l}\text { Imperfect housewife } \\
\mathrm{G}\end{array}$} & \multicolumn{2}{|l|}{ Divorce } \\
\hline $\begin{array}{l}\text { Mr. } \\
\text { Durant }\end{array}$ & Rose & Fan & $\begin{array}{l}\text { Submissi } \\
\text { ve lover }\end{array}$ & $\begin{array}{l}\text { Submissi } \\
\text { ve wife }\end{array}$ & $\begin{array}{l}\text { Indignantly } \\
\text { leaves }\end{array}$ & $\begin{array}{l}\text { Benevole } \\
\text { ntly stays }\end{array}$ \\
\hline $\begin{array}{l}\text { A certain } \\
\text { lady }\end{array}$ & \multicolumn{2}{|c|}{ Mrs. Legion } & \multicolumn{2}{|c|}{$\begin{array}{l}\text { Snobbish housewife } \\
\text { BC-F-G-R-RI }\end{array}$} & \multicolumn{2}{|c|}{ Ignored husband } \\
\hline $\begin{array}{l}\text { The } \\
\text { Wonderful } \\
\ldots\end{array}$ & Allie Bain & $\begin{array}{l}\text { Hattie } \\
\text { Whitta } \\
\text { ker }\end{array}$ & $\begin{array}{l}\text { Imperfect } \\
\text { housewif } \\
\text { e NF }\end{array}$ & $\begin{array}{l}\text { Perfect } \\
\text { housewif } \\
\text { e }\end{array}$ & Married & Married \\
\hline $\begin{array}{l}\text { Dialogue } \\
\text { at three } \\
\text { in... }\end{array}$ & $\begin{array}{l}\text { Unknown } \\
\text { name }\end{array}$ & $\begin{array}{l}\text { Jeanne } \\
\text { tte }\end{array}$ & $\begin{array}{l}\text { Flapper } \\
\text { A- BC-F- } \\
\text { W }\end{array}$ & $\begin{array}{l}\text { Flapper } \\
\text { B }\end{array}$ & Friend & Friend \\
\hline $\begin{array}{l}\text { The last } \\
\text { tea }\end{array}$ & $\begin{array}{l}\text { Unknown } \\
\text { name }\end{array}$ & $\begin{array}{l}\text { Carol } \\
\text { Mc } \\
\text { Call }\end{array}$ & $\begin{array}{l}\text { Girl AC- } \\
\text { C-G-NA }\end{array}$ & $\begin{array}{l}\text { Flapper } \\
\text { A-G-M- } \\
\text { SB }\end{array}$ & Friend & Admirer \\
\hline $\begin{array}{l}\text { Oh! } \\
\text { He's... }\end{array}$ & \multicolumn{2}{|c|}{ Miss Waldron } & \multicolumn{2}{|c|}{ Admirer G-R } & \multicolumn{2}{|c|}{ Lets her admire him } \\
\hline $\begin{array}{l}\text { Travelogu } \\
\mathrm{e}\end{array}$ & \multicolumn{2}{|c|}{ Unknown name } & \multicolumn{2}{|c|}{$\begin{array}{l}\text { Snobbish housewife } \\
\text { C-F-RI-T }\end{array}$} & \multicolumn{2}{|c|}{ Submissive husband } \\
\hline $\begin{array}{l}\text { Little } \\
\text { Curtis }\end{array}$ & \multicolumn{2}{|c|}{ Laura Matson } & \multicolumn{2}{|c|}{ Perfect housewife $\mathrm{G}$} & \multicolumn{2}{|c|}{ Perfect husband } \\
\hline The sexes & $\begin{array}{l}\text { Unknow } \\
\text { n name }\end{array}$ & $\begin{array}{l}\text { Florence } \\
\text { Leaming }\end{array}$ & $\begin{array}{l}\text { Flapper } \\
\text { F-G-S }\end{array}$ & Flapper & Boyfriend & Friend \\
\hline $\begin{array}{l}\text { Arrangem } \\
\text { ent in } \\
\text { black... }\end{array}$ & \multicolumn{2}{|c|}{ Unknown name } & \multicolumn{2}{|c|}{$\begin{array}{l}\text { Snobbish housewife } \\
\text { M RI }\end{array}$} & \multicolumn{2}{|l|}{ Married } \\
\hline $\begin{array}{l}\text { A } \\
\text { telephone } \\
\text { call } \\
\end{array}$ & \multicolumn{2}{|c|}{ Unknown name } & \multicolumn{2}{|l|}{ Girl } & \multicolumn{2}{|c|}{ Left by her lover } \\
\hline $\begin{array}{l}\text { A } \\
\text { terrible... }\end{array}$ & \multicolumn{2}{|c|}{ Unknown name } & \multicolumn{2}{|c|}{ Flapper A-RI } & \multicolumn{2}{|l|}{ Friend } \\
\hline $\begin{array}{l}\text { Just a little } \\
\text { one }\end{array}$ & $\begin{array}{l}\text { Unknow } \\
\text { n name }\end{array}$ & Edith & $\begin{array}{l}\text { Flapper } \\
\text { A-AC-F }\end{array}$ & $\begin{array}{l}\text { Flapper. } \\
\text { A-F }\end{array}$ & Friend & Friend \\
\hline $\begin{array}{l}\text { The } \\
\text { mantle of } \\
\text { whistler }\end{array}$ & \multicolumn{2}{|c|}{ Alice French } & \multicolumn{2}{|c|}{ Flapper C-F-FS-G-SI } & \multicolumn{2}{|l|}{ Admirer } \\
\hline The garter & \multicolumn{2}{|c|}{ Dorothy Parker } & \multicolumn{2}{|c|}{$\begin{array}{l}\text { Flapper C-F-FS-G-M- } \\
\text { R-T-W }\end{array}$} & Admirer & \\
\hline New York & Jean & & Lover & & Leaves her & \\
\hline
\end{tabular}




\begin{tabular}{|c|c|c|c|c|c|c|}
\hline \multicolumn{7}{|l|}{ to Detroit } \\
\hline Big blonde & \multicolumn{2}{|c|}{ Hazel Morse } & \multicolumn{2}{|c|}{$\begin{array}{l}\text { Gibson girl A-AC- } \\
\text { BC-G-RI-Sl-W }\end{array}$} & \multirow{2}{*}{\multicolumn{2}{|c|}{$\begin{array}{l}\text { Left by her lovers } \\
\text { Involuntarily engaged }\end{array}$}} \\
\hline $\begin{array}{l}\text { You were } \\
\text { perfectly }\end{array}$ & $\begin{array}{l}\text { Unknow } \\
\text { n name }\end{array}$ & Elinor & $\begin{array}{l}\text { Flapper } \\
\text { A-FS-G- } \\
\text { M-S1 }\end{array}$ & $\begin{array}{l}\text { Flapper } \\
\text { A-G }\end{array}$ & & \\
\hline $\begin{array}{l}\text { The cradle } \\
\text { of... }\end{array}$ & \multicolumn{2}{|c|}{ Unknown name } & \multicolumn{2}{|c|}{$\begin{array}{l}\text { Flapper A-An-FS-G- } \\
\text { M-RI-T }\end{array}$} & \multicolumn{2}{|l|}{ Friend } \\
\hline $\begin{array}{l}\text { But the } \\
\text { one on the } \\
\text { right }\end{array}$ & \multicolumn{2}{|c|}{ Mrs. Parker } & \multicolumn{2}{|c|}{$\begin{array}{l}\text { Flapper A-C-FS-G-R- } \\
\mathrm{T}\end{array}$} & \multicolumn{2}{|l|}{ Single } \\
\hline $\begin{array}{l}\text { Here we } \\
\text { are }\end{array}$ & \multicolumn{2}{|c|}{ Unknown name } & \multicolumn{2}{|c|}{ Girl AC-F-RI } & \multicolumn{2}{|l|}{ Just married } \\
\hline $\begin{array}{l}\text { Lady } \\
\text { with... }\end{array}$ & \multicolumn{2}{|c|}{ Mona Morrison } & \multicolumn{2}{|c|}{ Lover AC-RI } & \multicolumn{2}{|l|}{ Leaves her } \\
\hline $\begin{array}{l}\text { Dusk } \\
\text { before } \\
\text { fireworks }\end{array}$ & Kit & $\begin{array}{l}\text { Margot } \\
\text { Connie } \\
\text { Evie }\end{array}$ & \multicolumn{2}{|c|}{$\begin{array}{l}\text { Snobbish young } \\
\text { woman A-AC-F-G-T }\end{array}$} & \multicolumn{2}{|l|}{ Shared lover } \\
\hline $\begin{array}{l}\text { A } \\
\text { Young... }\end{array}$ & \multicolumn{2}{|c|}{ Unknown name } & \multicolumn{2}{|c|}{ Flapper A-F-FS-T } & \multicolumn{2}{|l|}{ Admirer } \\
\hline Horsie & $\begin{array}{l}\text { Ms. } \\
\text { Wilmart } \\
\text { h }\end{array}$ & $\begin{array}{l}\text { Camilla } \\
\text { Crugger }\end{array}$ & $\begin{array}{l}\text { Nurse } \\
\text { NB-NF- } \\
\text { W }\end{array}$ & $\begin{array}{l}\text { Rich } \\
\text { housewif } \\
\text { e. F-G }\end{array}$ & Spinster & $\begin{array}{l}\text { Happil } \\
\text { y } \\
\text { marrie } \\
\mathrm{d}\end{array}$ \\
\hline $\begin{array}{l}\text { Advice } \\
\text { to... }\end{array}$ & $\begin{array}{l}\text { Cynthia } \\
\text { Marion }\end{array}$ & $\begin{array}{l}\text { Sylvie } \\
\text { Peyton }\end{array}$ & Lover G & Girl G & $\begin{array}{l}\text { Ignored by her } \\
\text { lover }\end{array}$ & $\begin{array}{l}\text { Ignore } \\
\mathrm{d} \text { by } \\
\text { her } \\
\text { friend }\end{array}$ \\
\hline $\begin{array}{l}\text { From the } \\
\text { diary of } \\
\text { a... }\end{array}$ & \multicolumn{2}{|c|}{ Unknown name } & \multicolumn{2}{|c|}{$\begin{array}{l}\text { Snobbish woman C- } \\
\text { G-H-M-RI }\end{array}$} & \multicolumn{2}{|l|}{ Single } \\
\hline $\begin{array}{l}\text { Sentiment } \\
\ldots\end{array}$ & \multicolumn{2}{|l|}{ Rosalie } & \multicolumn{2}{|l|}{ Lover A } & \multicolumn{2}{|l|}{ Left by her lover } \\
\hline $\begin{array}{l}\text { Mrs. } \\
\text { Carrington } \\
\text { and... }\end{array}$ & $\begin{array}{l}\text { Mrs. } \\
\text { Carringt } \\
\text { on }\end{array}$ & $\begin{array}{l}\text { Mrs. } \\
\text { Crane }\end{array}$ & $\begin{array}{l}\text { Snobbish } \\
\text { housewif } \\
\text { e A-BC- } \\
\text { F-G-M }\end{array}$ & $\begin{array}{l}\text { Snobbish } \\
\text { housewif } \\
\text { e A-BC- } \\
\text { F-G }\end{array}$ & Married & $\begin{array}{l}\text { Marrie } \\
\mathrm{d}\end{array}$ \\
\hline $\begin{array}{l}\text { The } \\
\text { little... }\end{array}$ & \multicolumn{2}{|c|}{ Unknown name } & \multicolumn{2}{|l|}{ Woman R } & \multicolumn{2}{|l|}{ Unknown } \\
\hline The waltz & \multicolumn{2}{|c|}{ Unknown name } & \multicolumn{2}{|c|}{ Woman G-M } & \multicolumn{2}{|l|}{ Single } \\
\hline $\begin{array}{l}\text { The road } \\
\text { home }\end{array}$ & Marjorie & $\begin{array}{l}\text { Ms. } \\
\text { Cronin }\end{array}$ & Girl M & Girl A-M & Girlfriend & Friend \\
\hline $\begin{array}{l}\text { Glory in } \\
\text { the } \\
\text { daytime }\end{array}$ & $\begin{array}{l}\text { Mrs. } \\
\text { Murdock }\end{array}$ & $\begin{array}{l}\text { Hallie } \\
\text { Noyes } \\
\text { Lily } \\
\text { Winton }\end{array}$ & $\begin{array}{l}\text { Imperfect } \\
\text { housewif } \\
\text { e BC-G- } \\
\text { NA-NF }\end{array}$ & $\begin{array}{l}\text { Aging } \\
\text { snob } \\
\text { women } \\
\text { A-F-G- } \\
\text { H-S-SB- } \\
\text { W }\end{array}$ & Married & $\begin{array}{l}\text { Lover } \\
\mathrm{s}\end{array}$ \\
\hline
\end{tabular}

Table 2. Classification of female characters 
List of abbreviations: A: Alcohol. AC: Age conscious. B: Body conscious. C: Childish. F: Fashion. FS: Adopts French style. G: Gatherings. H: References to homosexuality. M: Fond of music. NA: Abstemious. NB: Unconcerned about physical appearance. NF: Unconcerned about fashion. R: Reading. RI: Racial issues. S: Smoking. Sl: Slang. SB: Connected to show business. T: Travelling. W: Works for the wages.

\section{Conclusions}

Through her collection of early short stories, and especially with the sketches featuring dates of generic couples, Dorothy Parker accomplished to describe her own panorama: an emerging middle or high-class youth, embedded into mass consumption, crazy celebrations and a profound change in habits implying new rules in the relationship between men and women yet to be assumed. The apparently fascinating new sceneries of amusement and dates hide bitter sufferings for women: her main characters are often disdained by men as either too fast or too boring, which leads them to jealousy, depression and unhealthy pressure on their appearance. Among the many characters fitting the condition of married women, two stereotypes are persistently shown: the tyrant and the submissive wife. There are no examples of harmony under the patriarchal paradigm. The model of the 'flapper', extensively reflected in her stories, and particularly in her sketches, provided new possibilities for the subversion of the damage implied on the traditional parameters. However, her main trait is snobbism, a quality which was already capital in Parker's depiction of their preceding and more conventional generation. Most women are shown with a presumptuous attitude, and the ones who keep themselves apart from it, and out from these two models of the wife and the flapper, are considered as socially unacceptable.

Yearning for social acceptance is mirrored under the new conventions of the times. 'Appearance' became a big issue thanks to the dissemination of cosmetics and large scale retail stores. This eventually led to more fragility due the need to fit into the new beauty conventions. 'Entertainment' among youngsters, so reinforced and diversified in the period of the Twenties, offered a new field for romance, though hardly for friendship under Parker's perspectives, due to the highly competitive attitude shown by her female characters. It was probably her own female condition and personal experience of the new phenomenon what inspired her version of the cliché, implying a much more non-mysterious view than the artificial, sterile model of the decadent femme fatale. Even when she can be sympathetic to the point to picture herself on several stories, she does not renounce to make fun of the intellectual and emotional limits of this posse. Hence, the concerns shown by the characters never go further than their appearance and the search for fun, which makes them appear arrogant and frivolous as well as completely ignorant and unconcerned about their counterparts' wishes or needs. 
Even when all this acid, yet humorous criticism of idle bourgeois ladies is almost unanimously acknowledged as her most remarkable literary value, over her career Parker refused to be considered as a satirist since she claimed to use as a protective shield for her own faults and not as a weapon (1937). Behind her severe judgment, applied to every female (stereo)type, lies a confessed feminist trying to warn women against inaction and vulnerabilities provoked by dependence on men (1954). Thence, the third and last aspect examined, 'bonds with men', becomes especially relevant in her work. Ultimately, despite all the apparent differences separating the traditional and modern couples coexisting in the corpus, both models are connected by the same bonds of tyranny and dependence. Despite all the humor in her words, Dorothy Parker portrays herself as a pessimist through the display of a discourse of ambivalent feminism denouncing how women actively contribute to their own oppression in a world where only the rich and insensitive can feel safe. Women feel invariably trapped in their love life as they are desperate when single and alienated when married. The second half of her production, comprising the next twenty-five years, would be less festive and more concerned with loneliness. As a counterpart, she would also explore women's new possibilities in academic or professional terms, systematically ignored in this corpus, and especially those of friendship and social commitment.

\section{WORKS CITED}

Adams, Franklin P. The diary of our own Samuel Pepys, Volumes 1 \& 2. New York: Simon \& Schuster, 1935.

Curnutt, Kirk. The Cambridge introduction to F. Scott Fitzgerald. 2004. 2nd ed. Cambridge: Cambridge University Press, 2007.

Fitzpatrick, Kevin. "Interview: Stuart Y. Silverstein: Q \& A" (1999). Web. 18 Oct. 2015. <http://www.dorothyparker.com/interview.htm>.

Frederickson, David. You might as well live. A play with a jazz trio, about Dorothy Parker. Unpublished manuscript.

Frewin, Leslie. The late Mrs. Dorothy Parker. New York: Macmillan, 1986.

Gaines, James R. Wit's End: The days and nights of the Algonquin Round Table. New York: Harcourt, Brace \& Jovanovich, 1977.

Goulet, Darin Patrick. Not much fun: A musical adapted from Dorothy Parker, 1997. Unpublished manuscript, Harvard University.

Kinney, Arthur F. Dorothy Parker. Boston: Twayne Publishers, 1978.

Meade, Marion. What Fresh Hell Is This? 1988. 2nd ed. New York: Penguin, Random House, 1988.

Melzer, Sondra R., ed. The rhetoric of rage: Women in Dorothy Parker. New York: Peter Lang, 2001.

Mencken, Henry Louis. "The flapper.” The Smart Set: A Magazine of Cleverness 2 (1915): 1-2. 
Millay, Edna St Vincent. A few figs from thistles. New York: Harper \& Brothers, 1922.

Miller, Nina. Making love modern. The intimate public worlds of New York's literary women. New York: Oxford University Press, 1999.

Millier, Brett C. Flawed light: American women poets and alcohol. Urbana, IL: University of Illinois, 2009.

Parker, Dorothy. "The flapper.” The New York Life January 26 (1922): 22.

---. "News item.” The New York World August 16 (1925): 11.

---. Not as deep as a well: Collected poems. New York: The Viking Press, 1936.

---. "Madrid Radio Broadcast." (1937). Web. 17 Oct. 2015. < http://spartacuseducational.com/USAparker.htm>.

---. “Interview.” The New York Herald Tribune. 18 October 2015 (1954).

---. Not much fun. The lost poems of Dorothy Parker. Compiled and with an Introduction by Stuart Y. Silverstein. New York: Scribner, 1996.

---. Complete stories. Colleen Breese, ed. Introduction by Regina Barreca. 1995. New York: Penguin Books, 2003.

---. The portable Dorothy Parker. Marion Meade, ed. New York: Penguin, 2006.

Parker, Dorothy \& Arnaud d'Usseau. 1954. The ladies of the corridor. With an Introduction by M. Meade. New York: Penguin Classics, 2008.

Patmore, Coventry Kersey Dighton. The angel in the house. London: G. Bell \& Son, 1897.

Pettit, Rhonda S. A gendered collision: Sentimentalism and Modernism in Dorothy Parker's poetry and fiction. Madison, NJ: Fairleigh Dickinson University Press; London: Associated University Presses, 2000.

---. The critical waltz: Essays on the work of Dorothy Parker. Madison, NJ: Fairleigh Dickinson University Press, 2005.

Rubinstein, Annette T. "Dorothy Parker deserves better.” Monthly Review. Vol. 40.8 (1989): 52.

Showalter, Elaine. A jury of her peers. American women writers from Anne Bradstreet to Annie Proulx. London: Virago, 2009.

The Dorothy Parker Society: Dorothy Parker's New York (Dot City) Web. 15 Oct. 2015. <http://www.dorothyparker.com/about.html >.

Thusing, Jenniffer. No sense saying goodnight, an adaptation of Dorothy Parker's stories. Unpublished manuscript, 2004.

Treichler, Paula A. "Trapped like a Trap in a Trap." Language and Style 13:4 (1980). In Rhonda S. Pettit, ed. The critical waltz: Essays on the work of Dorothy Parker. Madison, NJ: Fairleigh Dickinson University Press, 2005: 166-86. 
Villena, Luis Antonio de. "Dorothy Parker. Marion Meade." 2000. ElCultural.es. Web. 18 Oct. 2015. <www.elcultural.es/version_papel/LETRAS/2627/Dorothy_Parker>.

Wilson, Edmund. "A Toast and a Tear for Dorothy Parker." The New Yorker 20 May (1944): 67-68.

Received: 26 July 2015 Accepted: 21 October 2015 